\title{
The Allelopathic Potential of Pigeon peas in Puerto Rico' ${ }^{1}$
}

\author{
P. R. Hepperly and Manuel Diaz ${ }^{2}$ \\ ABSTRACT
}

In laboratory and field tests, pigeon pea leaf litter was associated with root tip necrosis, stunting, and reduced germination in seeds of soybeans, lablab beans, pigeon peas, and local weeds. Leaf litter harbored, and was substrate for, species of the fungal genera Pythium, Fusarium, and Rhizoctonia, which are often associated with similar symptoms in other plants. Extraction of leaf litter, with potassium hydroxide, eliminated fungal pathogens; however, the diluted and $\mathrm{pH}$ adjusted extracts $(\mathrm{pH}=6.2)$ still caused typical symptoms of root necrosis, stunting and germination loss. Weed species varied in their sensitivity to pigeon pea litter. Grasses were inhibited more than dicotyledons. The germination, emergence, and survival of pigweed increased under pigeon pea leaf litter. Accumulation of pigeon pea leaf litter commenced with the closing of the crop canopy and the shading, dying, and dropping of the lower leaves in the field. In fields planted to high densities of pigeon peas on the south coast of Puerto Rico, pigweed became the dominant weed under the pigeon pea canopy at harvest. Yield of residues was greater for stems than for roots or leaves and harvest index was low $(26 \%$ based on pod yield and $15 \%$ based on dry seed yield). Minimum thresholds for detecting plant inhibition by leaf litter in the laboratory was 5-10 grams of litter per square meter surface area, and approximately 25 grams of litter equivalents when using potassium hydroxide extracts. At harvest time, leaf litter in the field was greater than 150 grams per square meter which was close to the optimum levels for plant inhibition found in laboratory tests (100-200 grams of litter per square meter).

\section{INTRODUCTION}

The pigeon pea (Cajanus cajan (L.) Millsp.) is a tropical bush legume used for grain, fresh peas, or as a forage $(5,9)$. Pigeon peas were one of the earliest domesticated crops originating in the Indian center of crop domestication. Presently, India produces $90 \%$ of the world production of pigeon peas and has developed the vast majority of cultivated varieties. Most wild relatives of pigeon peas are found in eastern Asia. Pigeon peas were introduced to Puerto Rico during the 18th century by African slaves. The crop is harvested as green peas and is used as a favorite vegetable. Over 6,000 hectares are devoted to commercial production and the farm value of this crop exceeds 6 million annually (4). Pigeon peas are also widely grown as a kitchen or garden crop.

Green and mature pigeon peas have a high level of protein, and when

\footnotetext{
${ }^{1}$ Manuscript submitted to Editorial Board October 5, 1982.

${ }^{2}$ Assistant Professor of Plant Pathology and Graduate Research Assistant, respectively, Department of Crop Protection, College of Agricultural Sciences, University of Puerto Rico, Mayagüez.
} 
eaten at a ratio of $1: 3$ to $1: 5$ with cereals or root crops, they form an excellent dietary staple (9). Besides their nutritional value, pigeon peas are hardy plants which can tolerate low fertility, drought, and diseases better than most other grain legumes. For this reason, pigeon peas are often grown on marginal lands unsuitable for other crops. In Puerto Rico, pigeon pea production is centered in the droughty southern foothills where they are produced without supplemental irrigation or fertilization.

Although pigeon peas are popularly known for their weed suppression (6), there has been little or no experimental validation or explanation of the phenonemon. Allelopathy, the release of phytotoxic metabolites, is a possible mechanism for weed suppression (12). Most work on allelopathy has centered on the effects of certain weeds on crop plants and not vice versa (2). Phytotoxic metabolites, besides affecting weed competition, may affect cultural practices (11). Phytotoxic residues of crop plants may determine appropriate crop rotation, time of planting, and need for special soil preparation or residue management (5).

Biological succession of plant species in nature has been associated with self-inhibition of dominant plant species and their replacement with species with increased tolerance to phytotoxic principles (12).

In traditional areas of pigeon pea production in Puerto Rico, farmers are well aware of yield decline when pigeon peas are cultivated without crop rotation. For this reason, pigeon pea fields are followed with pasture. Normally pigeon peas are planted one or two years and the same area is then allowed to grow to weed pasture, which is utilized for one or two years. Management of pigeon peas is very different in the newly opened southern coastal region, which was previously devoted to sugarcane. Unlike the production in the traditional areas, pigeon pea production here utilizes both mechanization in planting and irrigation. In 1979, approximately $80 \%$ of this land was in continuous pigeon peas; however, currently less than $10 \%$ remains planted to this crop. In the new production area, pigeon peas were adopted because of their high yield, low production costs, and their ready local market. The continuous decline of pigeon pea yield in continuous culture has been the most cited reason for the decline of this crop in the new production area.

Yield declines have been blamed on declined fertility, increasing pest activity, and the buildup of toxic metabolites in the case of field succession. Experiments in Puerto Rico and in other pigeon pea producing countries have shown little response to supplemental fertility even on nutrient poor soils $(1,3,7,8,10)$. Likewise, disease surveys in Puerto Rico gave little support to the idea that soil pests were the primary cause of yield decline. For these reasons, studies were initiated to determine the allelopathic potential of pigeon peas in Puerto Rico. 


\section{MATERIALS AND METHODS}

Work was conducted at the College of Agriculture farm in Mayagüez, Puerto Rico. Five square frames $(40 \times 40 \mathrm{~cm})$ were tossed randomly and filled to $3 \mathrm{~cm}$ deep with dried pigeon pea leaves. A paired plot design was used with equal adjacent areas with and without treatment. Weeds were allowed to grow 1 month and then analyzed by being counted and weighed by species. The paired-t test was used to determine statistical significance.

After being harvested as described above, weeds were allowed to recolonize experimental plots for an additional month. Samples were also taken from adjacent nonweeded areas which had 2 months of uninterrupted weed growth. A complete block design with five replications was used. Data was analyzed for variance, and means were separated according to Fischer's Least Significant Difference (FLSD).

Weed succession was followed in experimental plantings of 0.25 ha of each "Kaki" and "2-B-Bushy" pigeon peas at the Fortuna Research Center of the University of Puerto Rico College of Agriculture. Weeds were sampled in a $50 \times 25 \mathrm{~cm}$ frame tossed four times randomly at 2,3 , $4,5,6$, and 7 weeks after planting. Weeds were separated by species and weighed. During the harvest, notes were taken on weed prevalence.

After harvesting pigeon pea grain, the yield of leaf litter, stems with attached leaves, and roots were determined by sampling $3 \mathrm{~m}^{2}$ areas in each of five random plots in the plantings used for the weed succession studies.

Soybean (Glycine $\max$ (L.) Merr.) cv. "Improved Pelican" was used to test the effect of dry pigeon pea leaves on seed germination and seedling growth in the laboratory. Either $0,1,10$, or 100 grams of dry pigeon pea leaves was blended with 1 liter water and used to irrigate a cellulose pad (Kimpac), which was used as a germination surface $\left(0.25 \mathrm{~m}^{2}\right)$. One hundred soybean seeds were germinated for each replicate. The experiment used a randomized complete block design with four replications per treatment. Seeds were incubated for 7 days at $28^{\circ} \mathrm{C}$ and $95 \% \mathrm{RH}$, after which time data was taken on germination frequency and on root and shoot growth. Root and shoot length were measured on 25 random seedlings per replicate. Germination values were analyzed for variance and means were separated with FLSD. The treatment root and shoot mean lengths and their respective standard errors were computed.

The germination and growth of pigeon peas cvs. "2-B-Bushy" and "Kaki," soybean cv. "Improved Pelican," and common lablab bean ( $L a$ blab purpureus (L.) Sweet) were assayed with either 0, 1, 10, 50, 100, or 500 grams of dry pigeon pea leaves as previously described. A randomized 
complete block design with four replications was used. Germination and fresh weight data were analyzed for variance, and means were separated by FLSD.

To eliminate the effects of Pythium, Fusarium, and Rhizoctonia species associated with pigeon pea leaves, 50 grams of pigeon pea leaves was extracted overnight in $200 \mathrm{ml}$ of $0.1 \mathrm{M}$ potassium hydroxide. The above extract was diluted five times with $0.1 \mathrm{M}$ monobasic phosphate buffering solution resulting in 1 liter of solution with a final $\mathrm{pH}$ of 6.2 . Concentrations of potassium and phosphate in the final solution were similar to those found in ordinary nutrient solutions. No pathogenic fungi were associated with this solution. The solution was serially diluted to give the equivalents of $25,12,6$, and $3 \mathrm{~g}$ of pigeon pea leaves (extracted) per liter, and the corresponding solutions were used to irrigate the cellulose pad as previously described. "Kaki" and "2-B-Bushy" pigeon peas were used as test plants. A complete randomized block design with four

TABLE 1.-Effect of pigeon pea leaf litter (PPLL) on weed number and growth

\begin{tabular}{|c|c|c|c|c|c|c|c|}
\hline \multirow{3}{*}{ Plot } & & \multicolumn{6}{|c|}{ Weed } \\
\hline & & \multicolumn{3}{|c|}{ Number } & \multicolumn{3}{|c|}{ Fresh weight (g) } \\
\hline & & PPLL & & $\mathrm{NT}^{1}$ & PPLL & & NT \\
\hline 1 & & 2 & & 60 & 1 & & 58 \\
\hline 2 & & 14 & & 232 & 6 & & 81 \\
\hline 3 & & 2 & & 400 & 4 & & 103 \\
\hline 4 & & 136 & & 451 & 66 & & 129 \\
\hline \multirow[t]{2}{*}{5} & & 47 & & 466 & 43 & & 154 \\
\hline & $(\overline{\mathrm{x}})$ & 40 & $* * 2$ & 322 & 24 & $* *$ & 105 \\
\hline
\end{tabular}

${ }^{1}$ Nontreated (control).

${ }^{2}$ Highly significant difference at $\mathrm{P}=0.01$ using the paired-t test.

replications of 100 seed each for each treatment was used. Germination and root lengths were measured after 2 weeks at $28^{\circ} \mathrm{C}$ and data was analyzed as previously described.

\section{RESULTS}

Total weed emergence and fresh weight was reduced significantly in plots with pigeon pea litter compared to that of paired nontreated plots (table 1). The reduction in weed number was found mostly for grasses but not for broadleaves (table 2). Pigeon pea leaf litter increased the emergence and fresh weight of pigweed (Amaranthus dubius) (table 2).

Pigeon pea leaf litter treatment which was weeded after 1 month showed less weed recolonization (number and fresh weight) after 2 months than either the 1-month weeded treatment without leaf litter or the 2-month nonweeded treatment (table 3 ). The 1 -month weeded treatment had significantly less weed growth than the 2-month nonweeded control. 
Grasses (jungle rice (Echinochloa colonum), red spangled top (Leptochloa filiformis), and large crabgrass (Digitaria sanguinalis) tended to increase until 6 weeks after planting and decline thereafter (fig. 1). Among broadleaves, spiderflower (Cleome gynandra) increased rapidly until 3 weeks after planting and then declined rapidly thereafter. Pigweed was the only weed which consistently increased throughout the sampling period. Pigeon pea leaf litter began to accumulate upon the closure of the pigeon pea canopy and the dying of the lower shaded branches.

TABLE 2.-Effect of pigeon pea leaf litter (PPLL) on weed community composition

\begin{tabular}{|c|c|c|c|c|c|c|c|c|c|}
\hline \multirow{3}{*}{ Plot } & \multicolumn{9}{|c|}{ Number } \\
\hline & \multicolumn{3}{|c|}{ Grasses } & \multicolumn{3}{|c|}{ Wild Poinsettia } & \multicolumn{3}{|c|}{ Pigweed } \\
\hline & PPLL & & $\mathrm{NT}^{1}$ & PPLL & & NT & PPLL & & NT \\
\hline 1 & 0 & & 47 & 0 & & 3 & 50 & & 48 \\
\hline 2 & 14 & & 50 & 28 & & 20 & 64 & & 4 \\
\hline 3 & 0 & & 44 & 0 & & 8 & 50 & & 6 \\
\hline 4 & 9 & & 60 & 1 & & 4 & 78 & & 24 \\
\hline 5 & 9 & & 22 & 45 & & 22 & 13 & & 10 \\
\hline$(\overline{\mathrm{x}})$ & 6.4 & $* * 2$ & 44.6 & 14.8 & $\mathrm{NS}^{3}$ & 11.4 & 51.0 & $* *$ & 18.4 \\
\hline
\end{tabular}

${ }^{1}$ Non-treated (control).

${ }^{2}$ Highly significant difference $(\mathrm{P}=0.01)$ between means based on paired-t test.

${ }^{3} \mathrm{NS}=$ no statistical difference between means based on paired $\mathrm{t}$-test.

TABLE 3.-Effect of pigeon pea leaf litter (PPLL) on weed number and growth after 2 months

\begin{tabular}{|c|c|c|c|}
\hline \multirow{2}{*}{ Treatment } & & \multicolumn{2}{|c|}{ Mean number of weeds $/$ plot $^{1}$} \\
\hline & & Number & Fresh weight (g) \\
\hline \multicolumn{4}{|l|}{ PPLL mulch } \\
\hline Weeded after 1 month & & 5.0 & 5.8 \\
\hline \multicolumn{4}{|l|}{ No mulch } \\
\hline $\begin{array}{l}\text { Weeded after } 1 \text { month } \\
\text { No mulch }\end{array}$ & & 36.6 & 24.4 \\
\hline No weeding & & 68.6 & 409.8 \\
\hline & LSD 0.01 & 7.4 & 10.4 \\
\hline
\end{tabular}

${ }^{1}$ Treatment means based on 5 replications each.

Pigweed was the only weed that survived under the canopy after pigeon pea flowering in this experiment. At harvest, pigweed stands appeared most dense at the border of the planting and the number and growth of this weed appeared to diminish away from the planting.

After the pigeon pea harvest (approximately $7,000 \mathrm{~kg} / \mathrm{ha}$ green pods or $2,000 \mathrm{~kg} / \mathrm{ha}$ dry seed), yield of nonharvested parts was calculated. Yield of leaf litter was $1,919 \mathrm{~kg} / \mathrm{ha}$. Yield of above ground stems and attached leaves was $12,665 \mathrm{~kg} / \mathrm{ha}$ and that of roots $2,250 \mathrm{~kg} / \mathrm{ha}$. On the 
basis of estimated dry weights of each of these components, a harvest index of $26 \%$ based on green pods and $16 \%$ based on dry seed was calculated.

Germination of soybean seeds incubated with 0, 4, 40, and 400 grams of pigeon pea leaves per square meter was $83,82,72$, and $62 \%$, respectively. Between the lowest dosages and the two highest dosages, the

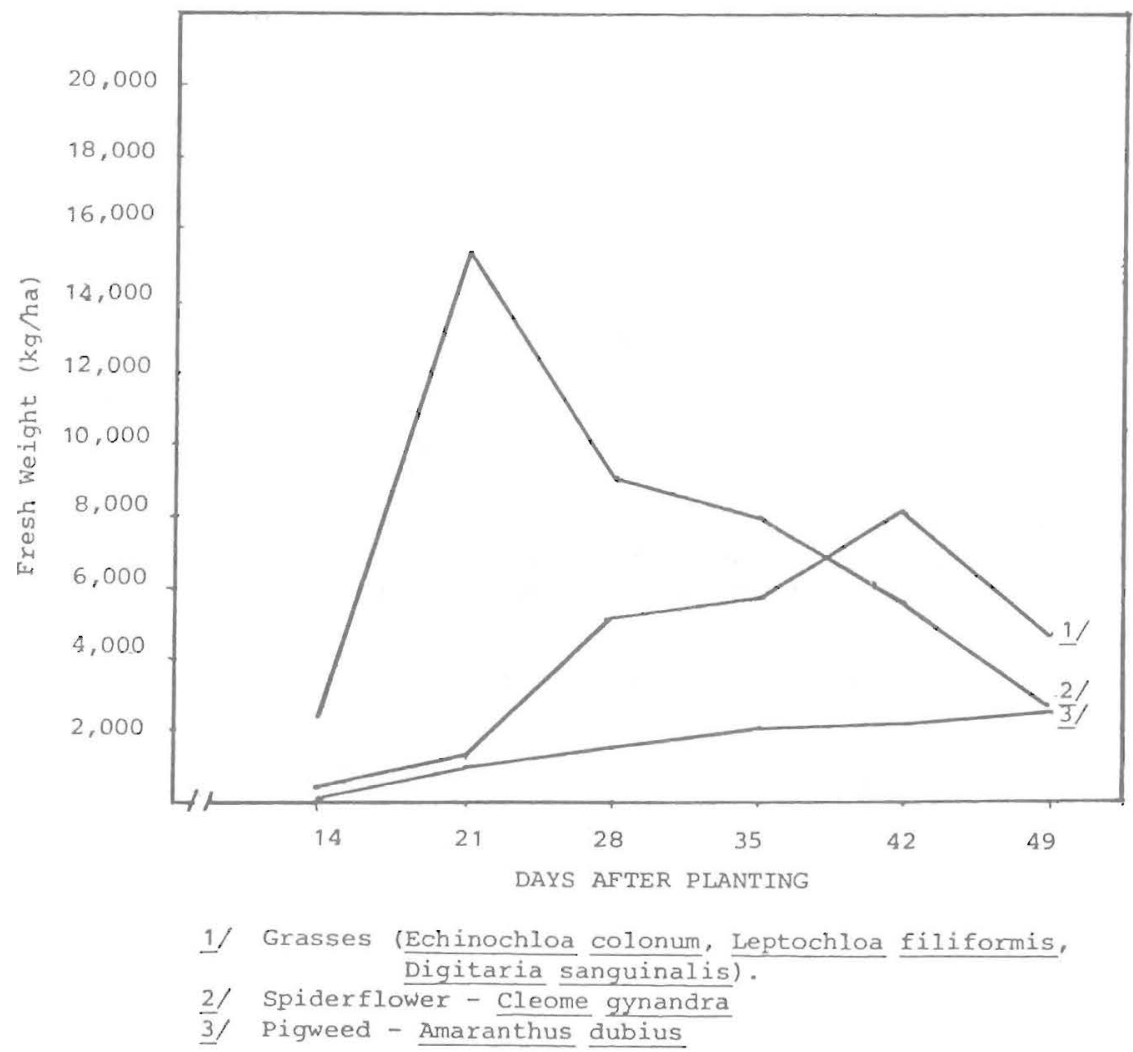

FIG. 1.-Accumulation of weed fresh weight during the initial 49 days of plantings of "Kaki" and "2-B-Bushy" pigeon peas in Fortuna, Puerto Rico.

difference was statistically significant $(P=0.01)$ (table 4$)$. Root lengths for the treatments were $5.2,5.0,3.9$, and $1.9 \mathrm{~cm}$, respectively, and shoot lengths were $15.1,14.9,12.8$, and $8.8 \mathrm{~cm}$, respectively. Root tip necrosis was the most notable symptoms expressed at increasing dosages of pigeon pea leaf litter.

In an expanded test, "Kaki" and "2-B-Bushy" pigeon peas, soybean cv. "Improved Pelican," and common lablab beans were used. Germination 
overall test plants was $69,62,43,26,33$, and $38 \%$ for $0,4,40,200,400$, and $2,000 \mathrm{~g}$ of pigeon pea leaves per square meter, respectively. For all test plants, most inhibition was found at $200 \mathrm{~g}$ of pigeon pea leaf litter (table 5). Fresh weight accumulation showed similar differences. Fresh weight inhibition was most marked for "Kaki" pigeon peas at $200 \mathrm{~g}$ of litter.

Extraction of pigeon pea leaves was used to eliminate fungal pathogens (Pythium, Rhizoctonia, and Fusarium species). With "Kaki" and "2-BBushy" pigeon peas as test plants, germination was $79,73,66,66$, and $65 \%$ for $0,12,24,48$ and 100 g equivalents of extracted pigeon pea leaf litter per square meter germination surface (table 6). There was little difference between the cultivars for either germination or root lengths. Root lengths at the increasing dosages were 19.4, 19.6, 11.3, 9.8, and 5.6 $\mathrm{cm}$, respectively. Maximum inhibition appeared at the highest dose in this experiment.

TABLE 4.-Effect of pigeon pea leaf litter on the germination and seedling growth of "Improved Pelican" soybean

\begin{tabular}{|c|c|c|c|c|}
\hline \multirow{2}{*}{ Pigeon pea litter } & & \multirow{2}{*}{ Germination } & \multicolumn{2}{|c|}{ Length $^{1}$} \\
\hline & & & Root & Shoot \\
\hline $\mathrm{g} / \mathrm{m}^{2}$ & & $\%$ & $\mathrm{~cm}$ & $\mathrm{~cm}$ \\
\hline 0 & & 83 & $5.2 \pm 0.2$ & $15.1 \pm 0.7$ \\
\hline 4 & & 82 & $5.0 \pm 0.2$ & $14.9 \pm 0.6$ \\
\hline 40 & & 72 & $3.9 \pm 0.2$ & $12.8 \pm 0.7$ \\
\hline \multirow[t]{2}{*}{400} & & 69 & $1.9 \pm 0.2$ & $8.8 \pm 0.6$ \\
\hline & LSD 0.01 & 7.5 & & \\
\hline
\end{tabular}

${ }^{1}$ Mean length annoted plus or minus standard error of the mean.

\section{DISCUSSION}

Pigeon pea leaves had an inhibitory effect on various weeds in Puerto Rico. The duration of this effect was measurable for at least 2 months after the application of litter. The inhibitory effect was selective. In our experiments grasses were most markedly inhibited whereas broadleaves showed little inhibition. Pigeon pea leaves appeared to stimulate the emergence and development of pigweed. On the south coast of Puerto Rico pigweed becomes the dominant weed in pigeon pea plantings, and the numbers and growth of this weed appear to decline as distance increases from pigeon pea plantings.

A minor proportion of the pigeon pea plant is harvested and used in Puerto Rico. More residues may be related to pigeon peas than many other crops because they are perennial in nature and require a long period before normal harvest. Of the total dry weight of pigeon peas, about one quarter is harvested as a green vegetable and about $15 \%$ as dry seeds. 
Leaves $(1,919 \mathrm{~kg} / \mathrm{ha})$ were a significant portion of the residue. Pigeon peas are usually grown in dry areas which are not conducive to rapid decomposition. It is probable that pigeon pea residues, which are not incorporated until just prior to planting, accumulate in continuous pigeon pea culture.

In laboratory tests, inhibition of various grain legumes appeared maximized at between 100 to $200 \mathrm{~g}$ of pigeon pea leaves per square meter germination surface. The minimum level for crop inhibition was between 5 to $10 \mathrm{~g}$ over the same surface. In our experimental fields approximately

TABLE 5.-Effect of pigeon pea litter on the germination, seedling fresh weight of pigeon pea and other grain legumes

\begin{tabular}{|c|c|c|c|c|c|c|}
\hline \multirow{2}{*}{ Plant } & \multicolumn{6}{|c|}{ Pigeon pea leaf litter $\left(\mathrm{g} / \mathrm{m}^{2}\right)$} \\
\hline & 0 & 4 & 40 & 200 & 400 & 2,000 \\
\hline & \multicolumn{6}{|c|}{ Germination } \\
\hline \multicolumn{7}{|l|}{ "Kaki" } \\
\hline Pigeon pea & 84 & 70 & 40 & 2 & 6 & 8 \\
\hline \multicolumn{7}{|l|}{ "2-B-Bushy" } \\
\hline Pigeon pea & 84 & 82 & 62 & 52 & 54 & 70 \\
\hline \multicolumn{7}{|l|}{ "Improved } \\
\hline \multicolumn{7}{|l|}{ Pelican" } \\
\hline Soybean & 88 & 78 & 48 & 40 & 58 & 50 \\
\hline \multirow[t]{4}{*}{ Lablab Bean } & 20 & 18 & 20 & 8 & 12 & 22 \\
\hline & $\overline{\mathbf{x}} \quad 69$ & $99 \quad 62$ & 43 & 26 & 33 & 38 \\
\hline & \multicolumn{6}{|c|}{ LSD Between Dose Means $0.01=4.2$} \\
\hline & \multicolumn{6}{|c|}{ Fresh weight $(g / 100$ seed) } \\
\hline \multicolumn{7}{|l|}{ "Kaki” } \\
\hline Pigeon pea & 27 & 21 & 5 & 1 & 2 & 1 \\
\hline \multicolumn{7}{|l|}{ "2-B-Bushy" } \\
\hline Pigeon pea & 22 & 15 & 13 & 9 & 12 & 13 \\
\hline \multicolumn{7}{|l|}{ "Improved } \\
\hline \multicolumn{7}{|l|}{ Pelican" } \\
\hline Soybean & 47 & 32 & 19 & 17 & 22 & 20 \\
\hline \multirow[t]{3}{*}{ Lablab Bean } & & 5 & 3 & 2 & 3 & 2 \\
\hline & $\overline{\mathrm{x}} \quad 26$ & $6 \quad 19$ & 10 & 7 & 10 & 9 \\
\hline & \multicolumn{6}{|c|}{ LSD Between Dose Means $0.01=3.6$} \\
\hline
\end{tabular}

$150 \mathrm{~g}$ of leaves was found per square meter, which is close to maximum levels for inhibitions observed in the laboratory. Maximum inhibition by pigeon pea leaves appears related not only to the direct toxicity of these leaves but also to their ability to serve as a substrate for soil borne fungal pathogens. Pathogen-free extracts caused typical inhibition but the severity of germination and fresh weight losses were reduced.

We feel that self inhibition of pigeon pea may be responsible for the decline of pigeon peas in coastal areas of Puerto Rico where they were produced in continuous culture. In 1976, pigeon pea plantings were 
initiated in a government vegetable project on retired sugarcane land. Plantings in the project reached 2,000 hectares, $80 \%$ of which was devoted to pigeon peas in 1978. Current production in the same area occupies less than $10 \%$. The reason most often cited for farmers reducing pigeon pea plantings is a progressive yield decline in fields continually planted to pigeon peas. Surveys of production fields in Puerto Rico have shown few nematode and root rot problems to account for yield decline. ${ }^{3}$ In Puerto Rico and elsewhere pigeon peas have shown little response to supplemental fertilizer $(1,3,7,8,10)$; thus, fertility decline may be an unlikely cause of pigeon pea decline.

In this study, pigeon pea allelopathy was related to leaf litter. In other studies we have detected plant inhibitors in root, stem and seed extracts. ${ }^{4}$

TABLE 6.-Effect of sterile potassium hydroxide extracts on pigeon pea leaf litter on the germination and seedling root growth of "Kaki" and "2-B-Bushy" pigeon peas

\begin{tabular}{|c|c|c|c|c|c|}
\hline \multirow{2}{*}{ Cultivar } & \multicolumn{5}{|c|}{ Extracted leaf litter $\left(\mathrm{g} / \mathrm{m}^{2}\right)^{1}$} \\
\hline & 0 & 3 & 6 & 12 & 25 \\
\hline & \multicolumn{5}{|c|}{ Germination } \\
\hline "Kaki" & 76 & 66 & 56 & 57 & 58 \\
\hline \multirow[t]{3}{*}{ "2-B-Bushy" } & 81 & 79 & 75 & 75 & 71 \\
\hline & $\overline{\mathbf{x}} \quad 78.5$ & 72.5 & 65.5 & 66.0 & 64.5 \\
\hline & \multicolumn{5}{|c|}{ LSD Between Dose Means $0.01=5.2$} \\
\hline "Kaki" & 18.6 & 17.2 & 11.8 & 10.3 & 4.7 \\
\hline \multirow[t]{3}{*}{ "2-B-Bushy" } & 20.2 & 22.1 & 10.8 & 9.2 & 6.4 \\
\hline & $\overline{\mathrm{x}} \quad 19.4$ & 19.6 & 11.3 & 9.8 & 5.6 \\
\hline & \multicolumn{5}{|c|}{ LSD Between Dose Means $0.01=2.7$} \\
\hline
\end{tabular}

${ }^{1}$ Each mean based on germination of 4 replicates of 100 seed for each dose and for each cultivar.

Furthermore, different plant organs appear to have chemically different inhibitors. For instance, it appears that in pigeon pea leaves, numerous glands secreting volatile terpenoid compounds may be responsible for phytotoxicity, whereas seed phytotoxicity is related to polyphenols (tannins), which are concentrated in the endoderm of the seedcoat. Clearly, the chemical nature of pigeon pea allelopathy deserves additional study.

Although this work has concentrated on the negative effects of pigeon pea allelopathy, further work with allelopathic crop plants should focus on their use in rotation, intercropping, and in mulching as a type of selective weed control. A particularly promising intercrop combination suggested by this work is that of pigweed or a related plant, possibly grain amaranth, and pigeon peas.

${ }^{3}$ P. Hepperly and R. Rodríguez, unpublished.

${ }^{4}$ P. Hepperly, unpublished data. 


\section{RESUMEN}

En pruebas de laboratorio y de campo, la hojarasca de gandul (Cajanus cajan (L.) Huth.) se asoció con necrosis de la punta de la raíz, supresión del crecimiento y germinación pobre de soya, habichuelas lablab, gandul y de ciertas malezas locales. La hojarasca de gandul albergó y sirvió de sustrato a especies de hongos de los géneros Pythium, Fusarium y Rhizoctonia, las cuales a menudo se asocian con síntomas similiares en otras plantas. Mediante una extracción de la hojarasca de gandul con hidróxido de potasio, se logró eliminar los hongos patógenos. Sin embargo, los extractos diluidos y con $\mathrm{pH}$ ajustado $(\mathrm{pH}=6.2)$, en igual forma causaron los síntomas típicos de necrosis de la punta de la raíz, supresión del crecimiento y pérdida de germinación. Las especies de malezas variaron en su sensitividad a la hojarasca de gandul. Las gramíneas fueron inhibidas más que las dicotiledóneas. La germinación, brotación y supervivencia del bledo (Amaranthus dubius Mart. ex Thell.) aumentó con los residuos de la hojarasca de gandul. La acumulación de la hojaraca comenzó con el cierre del cultivo, sombreando las hojas inferiores de la planta y por consiguiente su muerte y caída. En predios de la costa sur de Puerto Rico, donde se sembró el gandul densamente, el bledo llegó a ser la maleza predominante bajo el dosel de los arbustos al momento de la cosecha. El rendimiento de residuos de tallos fue mayor que el de las raíces u hojas. El índice de cosecha fue bajo ( $26 \%$ basado en rendimiento de vainas y $15 \%$ basado en rendimiento de semilla). En el laboratorio, el umbral mínimo para poder detectar inhibición en la planta causada por la hojarasca de gandul, fue de 5 a $10 \mathrm{~g}$ de hojarasca por metro cuadrado de superficie y aproximadamente 25 g equivalentes a la hojarasca al usar extractos sacados con hidróxido de potasio. Durante la cosecha, la hojarasca de gandul sobrepasó $150 \mathrm{~g}$ por metro cuadrado, cantidad similiar a los niveles óptimos necesarios para la inhibición de las plantas hallados en pruebas de laboratorio (100 a $200 \mathrm{~g}$ de hojarasca por metro cuadrado).

\section{LITERATURE CITED}

1. Badillo-Feliciano, J., Abrams, R. and Pietri, R., 1977. Effect of foliar-applied fertilizers on pigeonpeas (Cajanus cajan (L.) Millsp.), J. Agric. Univ. P.R. 61 (2): 217-20.

2. Bell, D. T. and Koeppe, D. E., 1972. Noncompetitive effects of giant foxtail on the growth of corn, Agron. J. 64: 321-25.

3. Del Valle, R., Jr., 1981. Influence of nutrition and bioregulators on flower retention, pod set, and yield of pigeon peas (Cajanus cajan (L.) Millsp.), J Agric. Univ. P.R. 65 (4): 346-52.

4. Estado Libre Asociado de Puerto Rico, 1981. Ingreso Agrícola de Puerto Rico, Oficina de Estadisticas, Departamento de Agricultura, San Juan, Puerto Rico.

5. Garb, S., 1961. Differential growth inhibitors produced by plants, Bot. Rev. 26: 42243.

6. Gooding, H. J., 1962. The agronomic aspects of pigeonpeas, Field Crop Abstr. 15: 1-15. 
7. Landrau, P. and Samuels, G., 1959. The effects of fertilizer applications on yields of pigeonpeas, J. Agric. Univ. P.R. 43 (1): 67-77.

8. Lugo-López, M. A. and Abrams, R., 1981. High yields of non-fertilized protein-rich pigeonpeas on tropical soils of low inherent fertility of Puerto Rico: an explanation of a paradox, J. Agric. Univ. P.R. 65 (1): 21-8.

9. Morton, J. F., 1976. The pigeonpea (Cajanus cajan (L.) Millsp.) a high-protein, tropical bush legume, Hort. Sci. 11 (1): 11-9.

10. Pietri, R., Abrams, R. and Julia, F. J., 1971. Influence of fertility level on the protein content and agronomic characters of pigeonpeas in an oxisol, J. Agric. Univ. P.R. 55: 474-77.

11. Putnam, A. R. and Duke, W. B., 1978. Allelopathy in agroecosystems, Ann. Rev. Phytopathology 16: 431-51.

12. Rice, E. L., 1974. Allelopathy, Academic Press, New York. 